\title{
Bilateral cytomegalovirus (CMV) oophoritis mimicking widely metastatic carcinoma: a case report and review of the literature Jing $\mathrm{Yu}^{1}$, Francis X Solano $\mathrm{Jr}^{2}$ and Raja R Seethala*1
}

Address: ${ }^{1}$ Department of Pathology, University of Pittsburgh Medical Center, Pittsburgh, PA 15213, USA and ${ }^{2}$ Solano \& Kokales Internal Medicine Associates, University of Pittsburgh Medical Center, Pittsburgh, PA 15213, USA

Email: Jing Yu - yuj@upmc.edu; Francis X Solano - solanofx@upmc.edu; Raja R Seethala* - seethalarr@upmc.edu

* Corresponding author

Published: 20 December 2007

Diagnostic Pathology 2007, 2:50 doi:10.1186/1746-1596-2-50

This article is available from: http://www.diagnosticpathology.org/content/2/1/50

(c) 2007 Yu et al; licensee BioMed Central Ltd.

This is an Open Access article distributed under the terms of the Creative Commons Attribution License (http://creativecommons.org/licenses/by/2.0), which permits unrestricted use, distribution, and reproduction in any medium, provided the original work is properly cited.
Received: 16 August 2007

Accepted: 20 December 2007

\begin{abstract}
Ovarian cytomegalovirus (CMV) infection is a rare finding reported in autopsy studies of immunocompromised patients. We report the first case of bilateral CMV oophoritis diagnosed in surgical resection specimens from a 63-year-old woman with metastatic brain lesions undergoing whole brain radiation and steroid treatment. The ovarian involvement of CMV infection was an incidental finding during the colectomy and bilateral salpingo-oophorectomy procedure for gastrointestinal bleeding and presumed ovarian metastases. In contrast to the prevailing dogma, a review of the literature found similar prevalence of pre-menopausal and post-menopausal cases. While age related vasculopathy was thought to be the prevailing mechanism for CMV oophoritis, the observation of an inflammation mediated microthrombosis in our case provides a plausible age independent mechanism suggesting that both restrictive and obstructive vascular changes can be involved in the pathogenesis of CMV oophoritis. To avoid misdiagnosis, both pathologists and clinicians should recognize ovarian involvement by CMV as a possibility in the immunocompromised patient.
\end{abstract}

\section{Background}

Cytomegalovirus (CMV) oophoritis has been rarely reported in the literature [1-10]. It usually occurs as an incidental finding in immunocompromised patients, either as part of a disseminated infection or as an isolated condition. We report here the first case of bilateral CMV oophoritis diagnosed in surgical resection specimens from a 63-year-old woman with metastatic brain lesions undergoing whole brain radiation and steroid treatment.

\section{Case presentation}

The patient was a 63-year-old woman with a history of lung cancer who presented with a three-week history of confusion and homonymous hemianopsia. On CT scan, she was found to have multiple hypodense cerebral lesions that were presumed to be metastases. She subsequently received whole brain radiation and steroids. Her post treatment course was complicated by heavy gastrointestinal bleeding from a duodenal ulcer. Three weeks subsequent to initiation of therapy, she developed a colonic perforation and underwent emergent laparotomy. The ovaries were also noted to be enlarged bilaterally and thought to be involved by metastatic disease. The patient underwent a left hemicolectomy and bilateral salpingooophorectomy. However, the patient's gastrointestinal bleeding persisted, and she passed away four days after surgery. A post-mortem examination was not performed. 


\section{Pathological findings}

On gross examination, both ovaries were edematous and showed cortical hemorrhage. The left ovary also demonstrated a $2.5 \mathrm{~cm}$ homogeneous calcific white nodule. Microscopic examination revealed extensive cortical coagulative necrosis within the areas of hemorrhage (Fig. 1A). In these hemorrhagic areas, there was a mixed inflammatory infiltrate accompanied by sheets and clusters of enlarged stromal and endothelial cells with abundant amphophilic cytoplasm, large intranuclear inclusions that formed characteristic perinuclear halos, and variable intracytoplasmic inclusions. Fibrin thrombi were identified within or adjacent to the lesional areas (Fig. 1B-C). An immunohistochemical stain for cytomegalovirus protein (clone DDG9+CCH2, dilution 1:50, Dako Cytomation) highlighted massive infiltration of ovarian cortex by CMV infected cells (Fig. 2A).

There were also prominent post-menopausal restrictive vascular changes throughout the surrounding ovary, con-

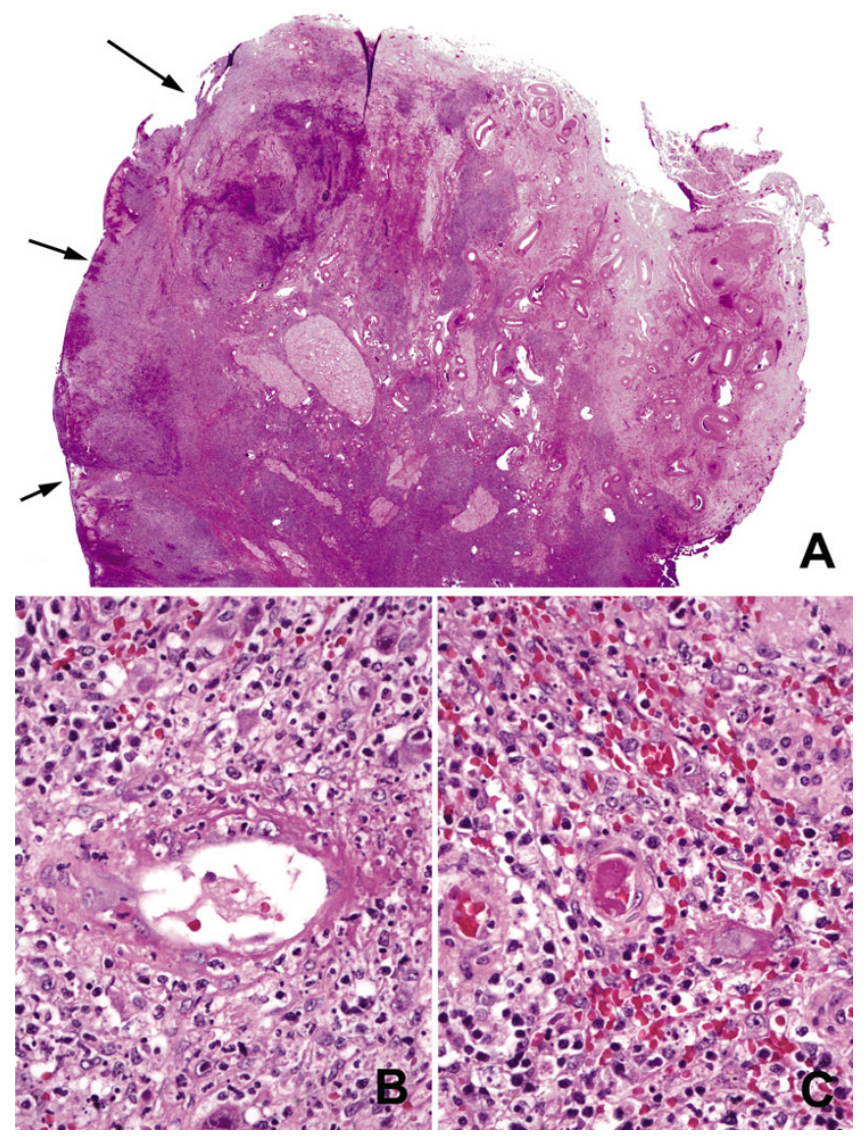

\section{Figure I}

(A) Areas of hemorrhage with extensive coagulative necrosis (arrows) (H\&E, whole slide scan, equivalent to magnification of approximately $\times 12$ ). (B) Vasculitis and (C) Fibrin microthrombus (H\&E, original magnifications $\times 400)$.

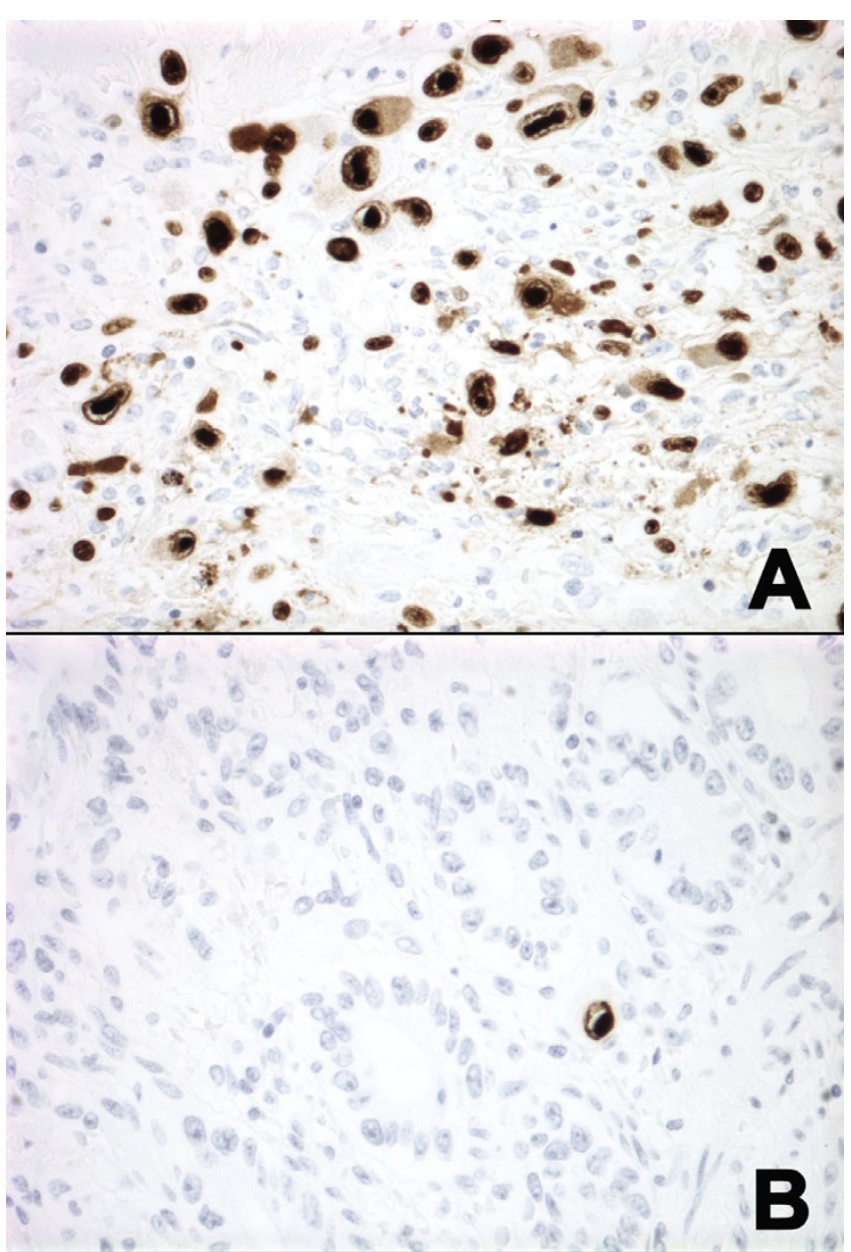

Figure 2

(A) Massive infiltration of ovarian cortex by CMV infected cells and (B) Scattered CMV positive cells in the colon (Immunoperoxidase, original magnification $\times 400$ ).

sisting of markedly thickened arterial walls with deposition of eosinophilic collagenous material (Fig. 3). The left ovary also contained a $2.5 \mathrm{~cm}$ ovarian fibroma.

The resected segment of colon demonstrated diverticulitis, including one ruptured diverticulum with a surrounding serositis. The fallopian tubes demonstrated an acute salpingitis. Immunohistochemical stains for CMV highlighted scattered positive cells in the lamina propria as well as in the serosa of the colon near the perforation (Fig. 2B).

\section{Discussion}

Previously, there have been 10 reports of 12 cases of CMV oophoritis in the English literature [1-10]. The main clinical features of all cases including the current case are summarized in Table 1 . The mean age at presentation was 44.7 (range: $11-67)$, and 7/13 (53.8\%) were post-menopausal. 


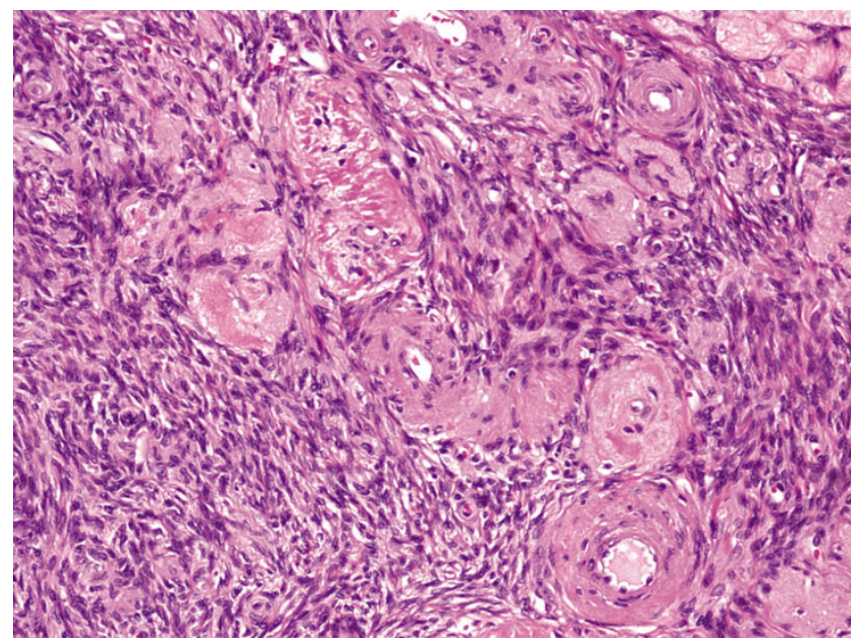

\section{Figure 3}

Prominent restrictive vascular changes (H\&E, original magnifications $\times 100)$.

All patients showed evidence of immunosuppression. Eight of thirteen $(61.5 \%)$ had pre- or post-mortem documentation of systemic involvement by CMV and two of these cases $(2 / 8,25 \%)$ received ganciclovir as treatment. Five of thirteen $(38.5 \%)$ had a clinical or gross presentation of mass lesion (s).

Originally described by Subietas et al in 1977 [8], bilateral CMV oophoritis is a rare pathologic finding that is usually associated with a systemic infection. An underlying malignancy or immunosuppressive status is almost always present and steroid therapy has been shown to be a strong risk factor for CMV reactivation in both groups $[5,8,11]$, as it is in our current case. It has been suggested that previously reported isolated CMV oophoritis might represent sampling error [7]. Indeed, the presence of a duodenal ulcer also raises the possibility that this incidental finding of bilateral oophoritis might have been part of a generalized CMV infection. However, there was no serologic or post-mortem documentation of systemic disease in this case.

It is worth noting that only slightly over half of the reported CMV oophoritis cases were from post-menopausal women $[1-3,5,9,10]$, even though it was historically thought to be a disease of post-menopausal patients [4,68]. This revised age distribution has some implications with regards to pathogenesis. The predilection of CMV for endothelial cells is thought to be important in the pathogenesis of CMV oophoritis. Initially, an explanation of the predilection of CMV oophoritis towards the post menopausal age was that the obstruction of blood flow secondary to age related restrictive vascular changes seen in postmenopausal women was a critical factor for localizing the infection to the ovary, thus allowing progression of disease $[3,8,10]$. The ovaries in our current case did indeed demonstrate prominent age related vascular changes in the post-menopausal ovaries, including eosinophilic collagen deposition and vessel wall thickening leading to narrowed lumina.

However, the subsequent inflammatory response and secondary vasculitis with microthrombi seen in our case also likely perpetuated this vascular restriction. CMV infected endothelial cells have been observed in the small vessels of the cortex in almost every reported case of CMV oophoritis, in both pre- and post-menopausal women (1-10). Generalized endothelial cell involvement in small vessels is a common phenomenon in multi-organ CMV disease [3]. Iwasaki et al. suggested that tissue involvement might begin with endothelial cell infection after the virus enters the ovary through bloodstream. The infected endothelial cells lining the vascular wall or those "desquamated" into the vascular spaces might have caused vascular obstruction, resulting in a localized vasculitis, thrombosis and secondary distal coagulative necrosis.

Additionally, mounting evidence suggests that CMV virus particles can directly initiate coagulation cascade and thrombin production $[12,13]$. In vitro studies suggest the activation of coagulation system mediated by tissue factor expression on the surface of infected endothelial cells, in combination with the essential phospholipids and tissue factor activity on modified CMV envelope [12,13]. In vivo studies demonstrate CMV-induced high factor VIII concentration and increased von Willebrand factor levels, suggesting a procoagulant response $[14,15]$. Numerous cases of acute thrombosis during CMV infection have been reported, manifested as either disseminated intravascular coagulation or localized organ specific infarct $[12,16]$.

The observation of multiple small vessel fibrin thromboemboli as seen in our case was not mentioned as a contributing factor in any of the previously reported CMV oophoritis cases. In fact, the lack of microthrombi was noted by Subietas et al [8] and actually considered one of the arguments against a virally induced vasculopathy. However, our case provides evidence for an alternate pathway for perpetuation of CMV infection in the ovary that does not require post menopausal restrictive vascular changes, thus providing one possible explanation for the nearly equal distribution between pre- and post- menopausal patients $[1-3,5,9,10]$.

The vast majority of reported cases were missed during the patients' lifetimes, except one case that was diagnosed in a patient who underwent surgical procedure for CMVassociated pelvic infectious disease and the ovarian 
involvement was limited to the left ovary [9]. Our current case is the first reported case of bilateral CMV oophoritis diagnosed in a surgical specimen for a patient with nongynecological disorders. Subietas et al [8] and LiVolsi and Merino [4] have previously emphasized the diagnostic challenge of CMV oophoritis both clinically and pathologically. Difficulties in diagnosis arise from inadequate sampling of macroscopically normal-sized ovaries, the assumption that enlarged ovaries are involved by metastatic disease, particularly when there is a known concurrent malignancy, and the similar microscopic appearance of massive CMV infection to a malignant infiltrate. The ovarian changes in our case were initially presumed to be metastatic tumors by the surgeon. In fact, $38.5 \%$ of previously reported cases did indeed grossly mimic tumors or mass lesions. Despite the lack of direct symptomatology from the oophoritis, all reported cases demonstrated cortical destruction and extensive histologic involvement by CMV infected cells. The cells enlarged by both nuclear and cytoplasmic inclusions may mimic an anaplastic carcinoma, melanoma or a large cell lymphoma, and thus awareness of the entity of CMV oophoritis is tantamount to its recognition $[3,8]$.

It is unclear whether ovarian CMV infection is a manifestation of systemic infection or actually the primary site of involvement. The putative vascular/restrictive pathogenesis model described above along with cases of isolated
CMV oophoritis [5,7] make the ovaries plausible candidates to serve as CMV reservoirs. Additionally, CMV DNA has been identified in arterial wall smooth muscle cells in both seropositive and seronegative healthy individuals [17]. However, the fact remains that most CMV oophoritis cases have been associated with concurrent multiorgan involvement, making it difficult to make any conclusive statements regarding CMV manifestation in the ovary [1$3,6,8,10]$. Furthermore, data on the role of the ovary in CMV latency is sparse [17-20].

Antiviral agents such as ganciclovir are the treatment of choice for CMV infection. In the two cases that had premortem documentation of systemic CMV infection and were treated with ganciclovir, post-mortem studies revealed continuing systemic infection in one case [2] and an isolated CMV oophoritis in the other case [6] (Table 1). The residual isolated CMV oophoritis after ganciclovir treatment illustrated the resistance to ganciclovir in the ovaries. It has been postulated that decreased blood flow in the postmenopausal ovary might reduce the ganciclovir level in ovarian tissue and help sequester CMV from antiviral treatment [6].

Hence in summary, CMV oophoritis is a rare occurrence that may affect both post- and pre-menopausal women who are immunocompromised. Observations of this case suggest that vascular changes, both native (restrictive) and

Table I: Main clinical features of reported CMV oophoritis cases in the English literature

\begin{tabular}{|c|c|c|c|c|c|c|c|c|}
\hline First Author & Age & $\begin{array}{l}\text { Menopausal } \\
\text { Status }\end{array}$ & $\begin{array}{l}\text { Primary } \\
\text { Diagnosis }\end{array}$ & $\begin{array}{l}\text { Prior } \\
\text { Immunosuppressive } \\
\text { Treatment/State }\end{array}$ & $\begin{array}{l}\text { Documented } \\
\text { Systemic CMV } \\
\text { infection }\end{array}$ & $\begin{array}{l}\text { Treatment } \\
\text { of CMV }\end{array}$ & $\begin{array}{l}\text { Presentatation } \\
\text { as Mass lesion }\end{array}$ & $\begin{array}{l}\text { Diagnostic } \\
\text { Material }\end{array}$ \\
\hline $\begin{array}{l}\text { Subietas } \\
\text { (1977) }\end{array}$ & 62 & Post-menopausal & Astrocytoma & Radiation & Yes (post-mortem) & No & No & Autopsy \\
\hline $\begin{array}{l}\text { Subietas } \\
\text { (1977) }\end{array}$ & 40 & Post-menopausal & $\begin{array}{l}\text { Hodgkin } \\
\text { Lymphoma, }\end{array}$ & $\begin{array}{l}\text { Chemotherapy, } \\
\text { Steroids, Radiation }\end{array}$ & Yes (post-mortem) & No & No & Autopsy \\
\hline $\begin{array}{l}\text { Subietas } \\
\text { (1977) }\end{array}$ & 67 & Post-menopausal & Breast CA & $\begin{array}{l}\text { Testosterone, } \\
\text { Steroids }\end{array}$ & No & No & No & Autopsy \\
\hline Evans (1978) & 37 & Pre-menopausal & SLE & Steroids & Yes (post-mortem) & No & Yes & Autopsy \\
\hline LiVolsi (1979) & 61 & Post-menopausal & Lymphoma & $\begin{array}{l}\text { Chemotherapy, } \\
\text { Steroids }\end{array}$ & Yes (post-mortem) & No & No & Autopsy \\
\hline Iwasaki (1988) & II & Pre-pubertal & ALL & $\begin{array}{l}\text { Chemotherapy, } \\
\text { Steroids }\end{array}$ & Yes (pre-mortem) & $\mathrm{N} / \mathrm{A}$ & No & Autopsy \\
\hline $\begin{array}{l}\text { Williams } \\
\text { (1989) }\end{array}$ & 40 & Pre-menopausal & Cholangio-CA & Liver Transplant & Yes (post-mortem) & No & Yes & Autopsy \\
\hline $\begin{array}{l}\text { Familiari } \\
(1990)\end{array}$ & 33 & Pre-menopausal & AIDS & Anti-retrovirals & Yes (pre-mortem) & Yes & No & Autopsy \\
\hline Sharma (1994) & 50 & Post-menopausal & Breast CA & Autologous BMT & No & No & No & Autopsy \\
\hline Wales (1996) & 31 & Pre-menopausal & HIV, PID & Anti-retrovirals, & No & No & $\begin{array}{l}\text { Yes (limited to } \\
\text { left ovary) }\end{array}$ & $\begin{array}{l}\text { Surgical } \\
\text { Resection }\end{array}$ \\
\hline Nieto (1999) & 50 & Post-menopausal & Breast CA & Allogenic BMT & $\begin{array}{l}\text { Yes (pre-mortem) } \\
*\end{array}$ & Yes & No & Autopsy \\
\hline $\begin{array}{l}\text { Manfredi } \\
(2000)\end{array}$ & 36 & Pre-menopausal & AIDS & $\begin{array}{l}\text { Presumed CNS } \\
\text { Toxoplasmosis \& } \\
\text { Lymphoma }\end{array}$ & No & No & Yes & Autopsy \\
\hline $\begin{array}{l}\text { Current Case } \\
(2007)\end{array}$ & 63 & Post-menopausal & Lung CA & Radiation, Steroids & No & No & Yes & $\begin{array}{l}\text { Surgical } \\
\text { Resection }\end{array}$ \\
\hline
\end{tabular}

ALL: acute lymphocytic leukemia; BMT: bone marrow transplantation; CA: carcinoma; CNS: central nervous system; PID: pelvic infectious disease; SLE: systemic lupus erythematosus; N/A: not available; *: pre-mortem systemic CMV infection but post-mortem isolated oophoritis 
virally induced (obstructive), represent viable pathogenetic mechanisms. Despite the lack of direct symptomatology, CMV oophoritis often presents as a mass lesion, and characteristically shows extensive cortical destruction and a high burden of virally infected cells. However, it is still unclear whether CMV reactivation in the ovaries is only a component of systemic spread or the actual primary site of origin of disease. To avoid misdiagnosis or underdiagnosis, both pathologists and clinicians should recognize ovarian involvement by CMV as a possibility in the immunocompromised patient.

\section{Competing interests}

The author(s) declare that they have no competing interests.

\section{Authors' contributions}

All authors have contributed to the content and design of this study.

\section{Acknowledgements}

Consent was obtained from the patient's relative before publication.

\section{References}

I. Evans DJ, Lampert IA: Ovarian involvement by cytomegalovirus. Hum Pathol I978, 9(I): 122.

2. Familiari U, Larocca LM, Tamburrini E, Antinori A, Ortona L, Capelli A: Premenopausal cytomegalovirus oophoritis in a patient with AIDS. Aids I99|, 5(4):458-459.

3. Iwasaki T, Sakuma T, Satodate R, Takano N, Sata T, Kurata T: Cytomegalovirus oophoritis with cortical necrosis during remission of acute lymphocytic leukemia. Acta Pathol Jpn 1988, 38(8): 1069-1076.

4. LiVolsi VA, Merino MJ: Cytomegalovirus infection of ovarian thecoma. Arch Pathol Lab Med 1979, I03(I 2):653-654.

5. Manfredi R, Alampi G, Talo S, Calza L, Tadolini M, Martinelli GN, Chiodo F: Silent oophoritis due to cytomegalovirus in a patient with advanced HIV disease. Int J STD AIDS 2000, II(6):4I0-4I2.

6. Nieto Y, Ross M, Gianani R, Shpall EJ, Cagnoni PJ, Bearman SI, Jones RB: Post-mortem incidental finding of cytomegalovirus oophoritis after an allogeneic stem cell transplant. Bone Marrow Transplant 1999, 23( ( 2): | 323-I 324.

7. Sharma TM, Nadasdy T, Leech RW, Kingma DW, Johnson LD, Hanson-Painton O: In situ DNA hybridization study of 'primary' cytomegalovirus (CMV) oophoritis. Acta Obstet Gynecol Scand 1994, 73(5):429-431.

8. Subietas A, Deppisch LM, Astarloa J: Cytomegalovirus oophoritis: ovarian cortical necrosis. Hum Pathol 1977, 8(3):285-292.

9. Wales NM, Nordin AJ, Newell AN, Smith JR, Barton SE, Nelson MR: Cytomegalovirus infection in the genital tract of HIV-seropositive women. Aids 1996, 10(7):802-803.

10. Williams DJ, Connor P, Ironside JW: Pre-menopausal cytomegalovirus oophoritis. Histopathology 1990, 16(4):405-407.

II. Shimizu K, Kishikawa M, Sekine I, Nishimori I, Kawajiri A: Disseminated intravascular coagulation induced by generalized cytomegalic inclusion disease during steroid therapy for polymyositis. Acta Pathol Jpn I 985, 35(3):723-730.

12. Squizzato A, Gerdes VE, Buller HR: Effects of human cytomegalovirus infection on the coagulation system. Thromb Haemost 2005, 93(3):403-410.

13. Sutherland MR, Raynor CM, Leenknegt H, Wright JF, Pryzdial EL: Coagulation initiated on herpesviruses. Proc Natl Acad Sci USA 1997, 94(25): 13510-135|4.

14. Schambeck CM, Hinney K, Gleixner J, Keller F: Venous thromboembolism and associated high plasma factor VIII levels: linked to cytomegalovirus infection? Thromb Haemost 2000, 83(3):5|0-5|I.
15. The TH, Kas-Deelen AM, de Maar EF, Driessen C, Harmsen MC, van Son WJ: Cellular and humoral parameters for vascular damage in blood during cytomegalovirus infections. Transplant Proc 200I, 33(I-2): I8I3.

16. Abgueguen P, Delbos V, Chennebault JM, Payan C, Pichard E: Vascular thrombosis and acute cytomegalovirus infection in immunocompetent patients: report of 2 cases and literature review. Clin Infect Dis 2003, 36(I I):EI34-139.

17. Hendrix RM, Wagenaar M, Slobbe RL, Bruggeman CA: Widespread presence of cytomegalovirus DNA in tissues of healthy trauma victims. J Clin Pathol 1997, 50(I):59-63.

18. Koffron AJ, Hummel M, Patterson BK, Yan S, Kaufman DB, Fryer JP, Stuart FP, Abecassis MI: Cellular localization of latent murine cytomegalovirus. J Virol 1998, 72(1):95-103.

19. Koffron AJ, Patterson BK, Yan S, Kaufman DB, Fryer JP, Stuart FP, Abecassis MI: Latent human cytomegalovirus: a functional study. Transplant Proc 1997, 29(I-2):793-795.

20. Kondo K, Kaneshima H, Mocarski ES: Human cytomegalovirus latent infection of granulocyte-macrophage progenitors. Proc Natl Acad Sci USA 1994, 9 I(25): I I879- I 883.
Publish with Biomed Central and every scientist can read your work free of charge

"BioMed Central will be the most significant development for disseminating the results of biomedical research in our lifetime. "

Sir Paul Nurse, Cancer Research UK

Your research papers will be:

- available free of charge to the entire biomedical community

- peer reviewed and published immediately upon acceptance

- cited in PubMed and archived on PubMed Central

- yours - you keep the copyright
BiolMedcentral 